Available online on 15.09.2020 at http://ujpr.org
Universal Journal of Pharmaceutical Research
An International Peer Reviewed Journal
Open access to Pharmaceutical research is an open access article distributed under the terms of the Creative Commons Attribution-Non
Commercial Share Alike 4.0 License which permits unrestricted non commercial use,
provided the original work is properly cited
Volume 5, Issue 4, 2020

\title{
PREVALENCE OF INTESTINAL HELMINTHIASIS AND THEIR ASSOCIATION WITH EOSINOPHILIA AMONG SCHOOLCHILDREN IN WADIDHAHAR DISTRICT AT SANA'A GOVERNORATE, YEMEN Arwa Mohammed Othman ${ }^{1}{ }^{1}$, Abdulsalam Mohammed Al-Mekhalfi ${ }^{2}$ \\ ${ }^{I}$ Department of Microbiology and Immunology, Faculty of Medicine and Health Sciences, Sana'a University, Sana'a, Yemen. ${ }^{2}$ Parasitology Department, Faculty of Medicine and Health Sciences,Sana'a University, Sana 'a, Yemen.
}

\section{ABSTRACT}

Objectives: Allergy and parasitic infections are common causes of blood eosinophilia. Intestinal helminthiasis remains a major health problem in many developing countries. Eosinophils are an effector immune cell against parasites. The objective of this study was to determine the prevalence of intestinal helminthiasis and eosinophilia among primary schoolchildren in Wadi Dhahr district, Sana'a governorate, Yemen.

Subjects and methods: Four hundred and fourteen pupils were enrolled in this study. Blood and stool samples were collected from each pupil. Stool samples were examined using Hoffman's sedimentation method for the presence of worms' ova. Blood smears were stained with Giemsa stain and used for counting the eosinophils' percentages.

Results: Out of 414 specimens, the prevalence of intestinal helminths infections was 79(19\%) among schoolchildren; (52 (18\%) males and 27 (21\%) females). Eosinophilia was 134 (32\%) observed in the participated pupils; 86 (30\%) males and 48 (37\%) females. The age group 5-10 years had the highest frequent rate of eosinophilia with a statistically significant difference $\left(\chi^{2}=10.4\right.$, $P=0.002)$ and $60 \%$ of infected students with intestinal worms had eosinophilia $\left(\chi^{2}=32.8, P<0.001\right)$. Females had a higher rate of eosinophilia than males. The most common helminthiasis infections were hymenolepiasis $(10.6 \%)$ followed by ascariasis $(4.1 \%)$, enterobiasis $(2.7 \%)$, and taeniasis $(2.4 \%)$. The high rate of eosinophilia was recorded among students infected with Ascaris lumbricoides (82\%) followed by Enterobius vermicularis (73\%), Trichuris trichiura(67\%), Hymenolepis nana (59\%), and Taeniasaginata $(30 \%)$.

Conclusions: Intestinal helminthiasis still a common health problem among schoolchildrenin WadiDhahar district at Sana'a governorate, Yemen, and was found to be associated with high blood eosinophils. Eosinophilia was statistically significant among students infected with ascariasis, hymenolepiasis, and enterobiasis but not with taeniasis and trichuriasis.

Keywords: Intestinal helminthiasis, eosinophilia, schoolchildren, WadiDhar, Yemen.

Article Info: Received 1 July 2020; Revised 3 August; Accepted 5 September, Available online 15 September 2020

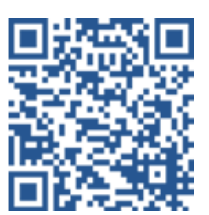

Cite this article-

Othman AM, Al-Mekhalfi AM. Prevalence of intestinal helminthiasis and their association with eosinophilia among schoolchildren in WadiDhahar district at Sana'a Governorate, Yemen. Universal Journal of Pharmaceutical Research 2020; 5(4):11-15.

DOI: https://doi.org/10.22270/ujpr.v5i4.433

Address for Correspondence

Arwa Mohammed Othman, Department of Microbiology and Immunology, Faculty of Medicine and Health Sciences, Sana'a University, Sana'a, Yemen, Tel: +967-774486417, E-mail: arwaothman@hotmail.com

\section{INTRODUCTION}

Typically, eosinophils' count in the blood is often less than $6 \%$ of the total blood leukocyte count. An increase in the eosinophil number, more than $6 \%$, is called eosinophilia. Varied disorders and etiologies may increase blood eosinophils which mainly include worm infections and allergic diseases. Parasitic infections are the most common cause of persistent eosinophilia in developing countries while atopic diseases such as eczema and asthma are the most common causes in developed countries ${ }^{1,2}$. In some parasitic infections, increase in the eosinophil number may be the only symptom ${ }^{3}$.
Eosinophilia may vary depending on the parasite development stage, parasite location in the body, parasite load, and co-infections with more than one parasite. Helminths which migrate into the tissues as part of their growth life cycle such as ascariasis induce persistent eosinophilia in both blood and tissues ${ }^{4,5}$. Globally 1.5 billion individuals were infected with intestinal helminths; of which more than 267 million pre-school children and above 568 million schoolchildren are considered at risk of morbidity, particularly in developing countries ${ }^{6}$. In 2010, anestimated 819 million individuals were infected with Ascarislum bricoides, 464 million with Trichuris 
trichura, and 438 million with Ancylostoma worms in the world ${ }^{7}$. In children, worm infections can cause significant malnutrition, delayed physical development, cognitive impairment while in adults; worms can reduce their productivity ${ }^{\mathbf{8 , 9 , 1 0}}$. Helminth infections have been associated with poor personal hygiene, environmental sanitation, and limited access to potable water $^{11}$ particularly in Yemen where most of people live under poverty line that lacks the effective programs for parasitic infection control and prevention $^{12,13,14}$. It was reported that the prevalence rate of intestinal parasitic infection was $62.7 \%$ recorded among schoolchildren in Ibb city ${ }^{13}$. Also, a study performed by Al-Mekhlafi et al., ${ }^{14}$ reported that the overall prevalence of intestinal parasitic infections was $17.2 \%$ among schoolchildren. In Yemen, there are several investigations that focused on the prevalence of intestinal parasitic infection among children school and associated with environmental factors. To date, data on the prevalence of intestinal helminthiasis associated with eosinophilia levels among schoolchildren are not available for Sana'a governorate, Yemen. Therefore, this study aimed to determine the prevalence of intestinal helminthiasis and its association with eosinophilia among schoolchildren at WadiDhahr district in Sana'a governorate, Yemen.

\section{MATERIALS AND METHODS}

Study design and area

A cross-sectional survey was conducted between January 2016 to June 2018 at two primary schools (AL-Wahda and AL-Mutanabi) situated in WadiDhahr locating about $15 \mathrm{Km}$ north of Sana'a, the capital of Yemen.

\section{Study population}

A total of 414 pupils, aged between 5-15 years, were enrolled in this study. Samples were chosen by using a simple random method from each school. One hundred and ninety-six samples were collected from students presented at AL-Wahda school while two hundred and eighteen samples were collected from AL-Mutanabi school.

\section{Exclusion criteria}

Students who were taking medications that may affect eosinophilia (e.g. penicillins and cephalosporins) or who had received anti-helminthic drugs within three months from the beginning of the study. Also, students known to have a food allergy or asthma were excluded from the study.

\section{Ethical considerations}

This study was approved by the Faculty of Medicine and Health Sciences, Sana'a University. Also, permission to conduct this study was approved by the office of educational authorities and school heads. Prior samples and data collection, the study objective was clarified to the parents, school teachers, and students. Oral consent was obtained from pupils' parents to participate in this study.

\section{Sample collection}

Two samples were obtained from each participant: blood and stool specimens. One gram of stool sample was emulsified in $7 \mathrm{ml}$ of $10 \%$ formalin for fixation ${ }^{15}$.Blood samples were collected by finger prick using disposable lancets. Blood smears were made from capillary blood on a glass slide, left to air dry, and then fixed with absolute methanol ${ }^{16}$.

Examination of stool specimens

Stool samples were examined using Hoffman's sedimentation method ${ }^{\mathbf{1 5}}$. Helminthic ova are concentrated by passing the fecal suspension through a gauze followed by centrifugation for two minutes at $1000 \mathrm{rpm}$. The upper liquid phase was discarded using a pipette. Two slides per fecal sample were prepared and read by two investigators ${ }^{15}$.

Examination of blood films

Differential blood count:

Fixed blood films were stained by Giemsa method. Blood films were washed and left to dry in air. Dried films were then examined microscopically using 40X and 100X objectives. One hundred white blood cells (WBC) were counted to determine the eosinophil percentages in the peripheral blood of each student. Eosinophil count greater than $6 \%$ was considered to be eosinophilia ${ }^{16}$.

\section{Statistical analysis}

The obtained results were analyzed using SPSS (Version 20). The statistical analysis was performed by using an odds ratio (OR), 95\% confidence interval (CI), Chi-square test $\left(\chi^{2}\right)$, and probability $(P)$ value $<0.05$ (significant) were used to determine the association between eosinophilia and helminths infection.

Table 1: Characteristics of schoolchildren participate in the study.

\begin{tabular}{lllllll}
\hline \multirow{2}{*}{ Characteristics } & \multicolumn{2}{c}{$\begin{array}{c}\text { Males } \\
(\mathbf{n = 2 8 5})\end{array}$} & \multicolumn{2}{c}{$\begin{array}{c}\text { Females } \\
(\mathbf{n = 1 2 9})\end{array}$} & \multicolumn{2}{c}{ Total } \\
\cline { 2 - 8 } & No. & $\mathbf{\%}$ & No. & \% & No. & $\%$ \\
\hline $\begin{array}{l}\text { Age groups } \\
\quad \text { 5-10 years }\end{array}$ & 45 & 16 & 22 & 17 & 67 & 16 \\
$\quad$ 11-15 years & 240 & 84 & 107 & 82 & 347 & 84 \\
\hline Mean age \pm SD* & \multicolumn{1}{c}{$12 \pm 1.7$} & & $12 \pm 1.7$ & & \\
\hline Intestinal helminths & & & & & & \\
Infected & 52 & 18 & 27 & 21 & 79 & 19 \\
Non-infected & 233 & 82 & 102 & 79 & 335 & 81 \\
\hline Eosinophilia & & & & & & \\
Yes & 86 & 30 & 48 & 37 & 134 & 32 \\
No & 199 & 70 & 81 & 63 & 280 & 68 \\
\hline Total & & & & & 414 & 100 \\
\hline
\end{tabular}


Table 2: Eosinophilia among students according to their gender, age groups and Intestinal helminthiasis

\begin{tabular}{|c|c|c|c|c|c|c|c|c|}
\hline & \multicolumn{2}{|c|}{ Eosinophilia } & \multicolumn{2}{|c|}{ Normal } & \multirow{2}{*}{ OR } & \multirow{2}{*}{ C.I } & \multirow{2}{*}{$\chi^{2}$} & \multirow{2}{*}{$\begin{array}{l}P \\
\text { value }\end{array}$} \\
\hline & No. & $\%$ & No. & $\%$ & & & & \\
\hline \multicolumn{9}{|l|}{ Age groups } \\
\hline $5-10$ & 33 & 49 & 34 & 51 & \multirow{2}{*}{2.4} & $1.39-$ & \multirow{2}{*}{10.4} & \multirow{2}{*}{0.002} \\
\hline $11-15$ & 101 & 29 & 246 & 71 & & 4.02 & & \\
\hline \multicolumn{9}{|l|}{$\begin{array}{l}\text { Intestinal } \\
\text { helminths }\end{array}$} \\
\hline Infected & 47 & 60 & 32 & 40 & \multirow{2}{*}{4.2} & $2.5-$ & \multirow{2}{*}{32.8} & \multirow{2}{*}{$\begin{array}{l}<0.00 \\
1^{*}\end{array}$} \\
\hline Non-infected & 87 & 26 & 248 & 74 & & 6.98 & & \\
\hline \multicolumn{9}{|l|}{ Gender } \\
\hline Males & 86 & 30 & 199 & 70 & \multirow{2}{*}{1.4} & $0.89-$ & \multirow{2}{*}{2} & \multirow{2}{*}{0.17} \\
\hline Females & 48 & 37 & 81 & 63 & & 2.12 & & \\
\hline
\end{tabular}

\section{RESULTS}

The present results showed that out of 414 participated schoolchildren; 285(69\%) were males and 129(31\%) were females. Also, 67(16\%) and 347(84\%) of student participants were aged, respectively, between-group of 5-15 years and 11-15 years. The frequency rate of infection with intestinal helminths was $79(19 \%)$ recorded among both males and females, while $335(81 \%)$ of participated were negative for an intestinal infection. The eosinophilia was 134(32\%) reported among the schoolchildren (Table 1). The current findings found that the age group 5-10 years had the highest frequent rate of eosinophilia compared to the age group 11-15 years with a statistically significant difference $\left(\chi^{2}=10.4, P=0.002\right)$. In addition, it was observed that the higher rate of eosinophilia $(60 \%)$ was recorded among students infected with intestinal parasites whereas $26 \%$ of non-infected students had eosinophilia $\left(\chi^{2}=32.8, P<0.001\right)$. The frequency of eosinophilia was higher among the females $(37 \%)$ compared to the males $(30 \%)$ with no statistical difference as listed in Table 2 .

Table 3: Types of worm infections among schoolchildren.

\begin{tabular}{lcc}
\hline Infection type & No. & \% \\
\hline Hymenolepiasis & 44 & 10.6 \\
Ascariasis & 17 & 4.1 \\
Enterobiasis & 11 & 2.7 \\
Taeniasis & 10 & 2.4 \\
Trichuriasis & 6 & 1.4 \\
Schistosomiasis & 2 & 0.5 \\
Mixed infection & 10 & 2.4 \\
\hline
\end{tabular}

The present results revealed that the hymenolepiasis was the most common intestinal worms among schoolchildren $(44 ; 10.6 \%)$, followed by ascariasis $(17$; $4.1 \%)$, enterobiasis $(11 ; 2.7 \%)$ and taeniasis (10; $2.4 \%)$. Also, $10(2.4 \%)$ of students were infected with more than on intestinal helminths (Table 3). Table 4 shows that the most frequent of eosinophilia rate was recorded among infected students with A. lumbricoides (82\%) followed by E.vermicularis (73\%), T. trichiura (67\%), H. nana (59\%), and T. saginata $(30 \%)$. Moreover, the eosinophilia was found in all pupils who were infected with more than one intestinal helminth. There was a statistical significance among students infected with $A$. lumbricoides, $H$. nana $(P<0.001)$, and E. vermicularis $(P<0.007)$. Nevertheless, no significant difference $(P>0.05)$ between infected participants with $T$. saginata and $T$. trichiura.

\section{DISCUSSION}

Intestinal parasitic infections are still major public health problems in developing countries and affect the poorest and most deprived communities. Soiltransmitted helminths impair the nutritional status and affect the general intelligence of the people they infect. Malnutrition has a significant impact on the growth and physical development of the infected children ${ }^{6,17}$. Current study confirms intestinal helminthiasis to remain a medical health problem in children from the two elementary schools at WadiDhahr district with a prevalence rate of $19 \%$. Intestinal helminths in current study are almost similar to those reported from Nepal $(20.4 \%)$ and Egypt $(21 \%)^{18,19}$.The prevalence rate of intestinal helminthiasis among schoolchildren in the present study was lower than that reported from Nigeria $(59 \%) 20$, India $(50 \%)$, and Ethiopia $(48 \%)^{20,21,22}$.The high prevalence of intestinal helminthiasis may reflect poor adhesion to preventive measures which helps re-infection to occur after dewormed programs performed by WHO. Hymenolepiasis was the most frequent intestinal helminthiasis among schoolchildren followed by ascariasis and enterobiasis. Current finding is consistent with studies conducted in Saudi Arabia and Egypt which reported $H$. nana to be the most common intestinal worm among schoolchildren ${ }^{23,24}$. However, current study disagrees with studies performed in Nigeria which found A. lumbricoides to be the most frequent intestinal helminth among Nigerian schoolchildren, and also from a study conducted in Nepal which reported $T$. trichiura to be the most common intestinal worm among schoolchildren ${ }^{20,25}$. The pattern of intestinal helminthiasis is found to vary geographically within the country (rural versus urban) and from country to country. This variation might be due to changes in the climate and other environmental factors that may support the survival of the infective stage in the soil for a long time ${ }^{26,27}$. Eosinophilia was common among school children infected with intestinal worms. Current finding is in agreement with those reported by Jiero et al., 2015 and Darlan et al., 2017, who found a significant association between soiltransmitted worms and high blood eosinophil count $^{28,29}$. This could be explained by fact that worm 
infections induce immune responses via $\mathrm{T}$ helper cell type 2 subset (Th2 cells). Th2 cells produce interleukin-4 (IL-4), IL-5, IL-10, and IL-13 which stimulate more production of eosinophils from bone marrow resulting in peripheral blood eosinophilia ${ }^{17,30-}$
33. The presence of blood eosinophilia without intestinal helminthiasis could be attributed to that students may have allergies, other worm infections such as urinary schistosomiasis, or a light number of parasites in the students' gastrointestinal tracts.

Table 4: Association of eosinophilia with different types of intestinal worms

\begin{tabular}{|c|c|c|c|c|c|c|c|}
\hline \multirow{2}{*}{ Species of worms } & \multicolumn{2}{|c|}{ Eosinophilia } & \multicolumn{2}{|c|}{ Normal } & \multirow[t]{2}{*}{$\chi^{2}$} & \multirow[t]{2}{*}{ C.I } & \multirow[t]{2}{*}{$P$ value } \\
\hline & No. & $\%$ & No. & $\%$ & & & \\
\hline Ascarislumbricoides & 14 & 82 & 3 & 18 & 20.2 & $0.026-0.329$ & $<0.001^{*}$ \\
\hline Hymenolepis nana & 26 & 59 & 18 & 41 & 16.1 & $0.150-0.542$ & $<0.001^{*}$ \\
\hline Enterobiusvermicularis & 8 & 73 & 3 & 27 & 8.4 & $0.045-0.654$ & $0.007^{*}$ \\
\hline Trichuris trichiura & 4 & 67 & 2 & 33 & 3.3 & $0.042-1.293$ & 0.089 \\
\hline Taeniasaginata & 3 & 30 & 7 & 70 & 0.03 & $0.285-4.399$ & 0.59 \\
\hline
\end{tabular}

Eosinophilia was significantly more frequent among children infected with Ascaris lumbricoides, Evermicularis, and $H$ nana. Similar observations were reported by other studies ${ }^{28,34-37}$.This could be explained by presence of tissue-invading larvae that migrate from the small intestine into blood circulation to reach lungs and elicit pulmonary inflammation ${ }^{4,38-40}$. Nevertheless, eosinophilia was non-significant among schoolchildren infected with $T$. trichiura and Taeniasaginata. This may be interpreted by worms that do not invade host tissues and thus do not come in contact with host immune system $^{41}$. Limitations for this study was neither availability of nearby laboratory to perform complete blood count in order to calculate absolute eosinophil counts nor refrigerator for sample storage until they were being investigated.

\section{CONCLUSION}

Current study indicates that eosinophil percentages for schoolchildren who were infected with intestinal helminthiasis were significantly higher than in schoolchildren who were not infected.

\section{ACKNOWLEDGEMENTS}

The authors are grateful to all students and teachers who participated in this study.

\section{CONFLICT OF INTEREST}

There is no conflict of interest related to this work.

\section{AUTHORS' CONTRIBUTIONS}

Authors contributed equally to the design, implementation, statistical analysis and manuscript drafting. All authors read and approved the final manuscript.

\section{REFERENCES}

1. Rothenberg M. Eosinophilia. N Engl J Med 1998; 338 (22):1592-1600. https://doi.org/10.1056/NEJM199805283382206

2. Kovalszki A, Weller PF.Eosinophilia. Prim Care 2016; 43(4):607-617.https://doi.org/10.1016/j.pop.2016.07.010

3. Ardiç N. An overview of Strongyloides stercoralis and its infections. Mikrobiyol Bul 2009; 43:169-77. PMID: 19334396

4. Nutman TB. Evaluation and differential diagnosis of marked, persistent eosinophilia. Immunol Allergy Clin North Am 2007; 27:529-549. https://doi.org/10.1016/j.iac.2007.07.008

5. Chinchilla RH. Eosinofilia y parasitosis. Rev Med Costa Rica y Centroamerica 2010; 593:241-244.

6. WHO. Soil-transmitted helminth infections; 2020.

7. Pullan RL, Smith JL, Jasrasaria R, Brooker SJ. Global numbers of infection and disease burden of Soil transmitted helminth infections in 2010. Parasites and Vectors 2014; 21(7):37. https://doi.org/10.1186/1756-3305-7-37

8. Hotez PJ, Bundy DP, Beegle $\mathrm{K}$, et al. Helminth infections: soil-transmitted helminth infections and schistosomiasis. Oxford University Press, Washington, 2006

9. Papier K, Williams GM, Luceres-Catubig R, et al. Childhood malnutrition and parasitic helminth interactions. Clin Infect Dis 2014; 59(2):234-43. https://doi.org/10.1093/cid/ciu211

10. Assoum M. The effects of helminth infections on child physical and cognitive development: an integrated pathophysiological and socioeconomic approach. Adv Life Sci Med 2015; 1(1):1-23.

11. Gelaw A, Anagaw B, Nigussie B, Silesh B, Yirga A, Alem M, Endris M, Gelaw B.Prevalence of intestinal parasitic infections and risk factors among schoolchildren at the University of Gondar Community School, Northwest Ethiopia: a cross-sectional study. BMC Public Health 2013; 3:304. https://doi.org/10.1186/1471-2458-13-304

12. Alshahethi MA, Edrees WH, Mogalli NM, et al. Distribution and risk factors for Giardia lamblia among children at Amran Governorate, Yemen. Universal J Pharm Res 2020; 5(3):34-37. https://doi.org/10.22270/ujpr.v5i3.413

13. Qasem EA, Edrees WH, Al-Shehari WA, Alshahethi MA. Frequency of intestinal parasitic infections among schoolchildren in Ibb city-Yemen. Universal J Pharm Res 2020; 5(2):42-46. https://doi.org/10.22270/ujpr.v5i2.388

14. Al-Mekhlafi AM, Abdul-Ghani R, Al-Eryani SM, SaifAli R, Mahdy MA.School-based prevalence of intestinal parasitic infections and associated risk factors in rural communities of Sana'a, Yemen. Acta Trop 2016; 163:135-141. https://doi:10.1016/j.actatropica.2016.08.009

15. Hoffman WA, Pons JA, Janer JL. The sedimentationconcentration method in Schistosomiasmansoni. Puerto Rican J Public Health Trop Med 1934; 2: 283-298.

16. Bain B, Lewis M. Preparation and staining methods for blood and bone marrow films In: Dacie and Lewis (ed) Practical Haematology. $10^{\text {th }}$ edn, Philadelphia, Churchill Livingstone 2006, pp59-77.

17. Jardim-Botelho A, Raff S, Rodrigues Rde A, et al. Hookworm, Ascaris umbricoides infection and polyparasitism associated with poor cognitive 
performance in Brazilian schoolchildren. Trop Med Int Health 2008; 13(8):994-1004.

https://doi:10.1111/j.1365-3156.2008.02103.x

18. Kunwar R, Acharya L, Karki S. Decreasing prevalence of intestinal parasitic infections among school-aged children in Nepal: a systematic review and metaanalysis. Trans R Soc Trop Med Hyg 2016; 110(6):324332. https://doi:10.1093/trstmh/trw033

19. Farghly AM, Mohamed SM, Abdel-Rahman SA, et al. The relation between the prevalence of soil-transmitted parasites in the soil and among school children in Zagazig district, Sharkyia Governorate, Egypt. J Parasit Dis 2016; 40(3): 1021-1029.

https://doi:10.1007/s12639-014-0627-z

20. Karshima SN. Prevalence and distribution of soiltransmitted helminth infections in Nigerian children: a systematic review and meta-analysis. Infect Dis Poverty 2018;7(1):69. https://doi:10.1186/s40249-018-0451-2

21. Salam N, Azam S. Prevalence and distribution of soiltransmitted helminth infections in India. BMC Public Health 2017; 17(1):201.

https://doi:10.1186/s12889-017-4113-2

22. Chelkeba L, Mekonnen Z, Alemu Y, Emana D. Epidemiology of intestinal parasitic infections in preschool and school-aged Ethiopian children: a systematic review and meta-analysis. BMC Public Health 2020; 20(1):117. https://doi:10.1186/s12889-020-8222-y

23. Omar MS, Abu-Zeid HA, Mahfouz AA. Intestinal parasitic infections in schoolchildren of Abha (Asir), Saudi Arabia. Acta Trop 1991;48(3):195-202. https://doi:10.1016/0001-706x(91)90047-n

24. Ibrahium FA. Prevalence and predisposing factors regarding intestinal parasitic infections among rural primary school pupils at Minia Governorate, Egypt. J Public Health Afr 2011; 2(2):e29. https://doi:10.4081/jphia.2011.e29

25. Shrestha A, Schindler C, Odermatt $\mathrm{P}$, et al. Intestinal parasite infections and associated risk factors among schoolchildren in Dolakha and Ramechhap districts, Nepal: a cross-sectional study. Parasit Vectors 2018; 11(1):532. https://doi:10.1186/s13071-018-3105-0

26. Silver ZA, Kaliappan SP, Samuel P, et al. Geographical distribution of soil transmitted helminths and the effects of community type in South Asia and South East Asia A systematic review. PLoSNegl Trop Dis 2018;12(1):e0006153.

https://doi:10.1371/journal.pntd.0006153

27. Ruberanziza E, Owada K, Clark NJ, et al. Mapping soiltransmitted helminth parasite infection in Rwanda: estimating endemicity and identifying at-risk populations. Trop Med Infect Dis 2019; 4(2):93. https://doi:10.3390/tropicalmed4020093

28. Jiero S, Ali M, Pasaribu S, Pasaribu A. Correlation between eosinophil count and soil-transmitted helminth infection in children. Asian Pacific J Trop Dis 2015; 5(10):813-816.

https://doi.org/10.1016/S2222-1808(15)60936-7

29. Darlan DM, Tala ZZ, Amanta C, Warli SM, Arrasyid NK. Correlation between soil-transmitted helminthinfection and eosinophil levels among primary school children in Medan. Open Access Maced J Med Sci 2017;5(2):142-146. https://doi:10.3889/oamjms.2017.014

30. Moreau E, Chauvin A. Immunity against helminths: interactions with the host and the intercurrent infections. J Biomed Biotech 2010; 2010:428593. https://doi:10.1155/2010/428593

31. Shamri R, Xenakis JJ, Spencer LA. Eosinophils in innate immunity: an evolving story. Cell Tissue Res 2011; 343(1):57-83. https://doi:10.1007/s00441-010-1049-6

32. Alcântara-Neves M, Britto1G, Veiga R, et al. Effects of helminth co-infections on atopy, asthma and cytokine production in children living in a poor urban area in Latin America. BMC Res Notes. 2014; 7:817. https://doi:10.1186/1756-0500-7-817

33. Weatherhead JE, Hotez JP. Worm infections in children. Ped Rev 2015; 36(8):341-354. https://doi:10.1542/pir.36-8-341

34. Kumar S, Jeong Y, Ashraf MU, Bae YS. Dendritic cellmediated Th2 immunity and immune disorders. Int $\mathbf{J}$ Mol Sci 2019; 20:2159-2186. https://doi:10.3390/ijms20092159

35. Sumagaysay JB, Emverda FM. Eosinophilia and incidence of soil-transmitted helminthic infections of secondary students of an indigenous school. Asian J Health 2011; 1 (1):172-184.

36. De-Farias SV, Silva E, Medeiros S, et al. Serum total $\mathrm{IgE}$, Ascarislumbricoides specific IgE and eosinophils in parasites-infected children in a tropical area. World Allergy Org J 2015; 8 Suppl 1:A223. https://doi:10.1186/1939-4551-8-S1-A223

37. Schroeder JC, Jones D, Maranich A. Peripheral eosinophilia found in pediatric Enterobius vermicularis infections. Clin Pediatr (Phila) 2019; 58(1):13-16. https://doi:10.1177/0009922818805193

38. Shin MH, Lee YA, Min DY. Eosinophil-mediated tissue inflammatory responses in helminth infection. Korean J Parasitol 2009; 47 Suppl: S125-S131. https://doi:10.3347/kjp.2009.47.S.S125

39. Mejia R, Nutman T. Evaluation and differential diagnosis of marked, persistent eosinophilia. Semin Hematol 2012; 49(2):149-159. https://doi:10.1016/j.iac.2007.07.008

40. Curtis C, Ogbogu PU. Evaluation and differential diagnosis of persistent marked eosinophilia. Immunol Allergy Clin North Am. 2015; 35(3):387-402. https://doi:10.1016/j.iac.2015.04.001

41. Heyneman D. Cestodes In: Baron S. Medical Microbiology. $4^{\text {th }}$ edition, The University of Texas, Galveston, 1996, chapter 89 